DOI 10.32900/2312-8402-2019-121-23-32

УДК 615.32:633.88

\title{
EFFECT OF ROSEMARY ESSENTIAL OIL ON LIPID PEROXIDATION IN THE VARIOUS PLANT OILS
}

\author{
Datsenka A., student \\ Kanavod H., student \\ Belaya L., student \\ Klimovich V., student \\ Truchan M., Ph.D.
}

Tkachenko H., Doctor of Biological Sciences

Institute of Biology and Environmental Protection, Pomeranian University in Słupsk, Poland

We hypothesized that rosemary essential oil would inhibit or reduce lipid oxidation in plant oils due to the antioxidative properties. The aim of this study was to investigate the content of 2-thiobarbituric acid reactive substances (TBARS) in the various plant oils (rapeseed oil, olive oil, rice oil) with the use of rosemary essential oil (Etja, Elblag, Poland) as antioxidant agent by monitoring the lipid peroxidation during one month storage period.

The effect of the interaction of the addition of REO and storage time on TBARS value in the rapeseed oil.

Lipid oxidation increased significantly $(p<0.001)$ during storage, particularly in the control sample (the rapeseed oil), which showed the highest increase at 8 days (19fold increased) and at 40 days (14.4-fold increased). The REO decreased lipid oxidation compared to the control sample by $23.9 \%$ ( $p<0.05)$ at 8 days and by $9.4 \%$ ( $p>0.05)$ at 40 days. At 15 days, the TBARS values reached approximately 22.31 umols $\cdot m L-1$, corresponding to a lipid oxidation increase of approximately $33.8 \%$ ( $p>0.05)$ for samples enriched by REO.

The rosemary essential oil decreased lipid oxidation in the rapeseed oil compared to the control sample by $23.9 \%(p<0.05)$ at 8 days and by $9.4 \%(p>0.05)$ at 40 days. Addition of rosemary essential oil to olive oil increased significantly TBARS values only at 8 days of the storage. The reduction of the lipid oxidation was the highest at 40 days as compared to the start of the study. Rosemary essential oil added to rice oil induced the increase of TBARS level at 8 days (by $23.7 \%, p<0.05$ ) and 0 days (by $64.4 \%, p<0.05)$, respectively. Lipid peroxidation retarding capacity of rosemary essential oil was found obviously promising. These antioxidant activities seem to be attributed to antioxidant compounds present in the rosemary essential oil.

Consequently, rosemary essential oil could be successfully added to various plant oils as a natural antioxidant source for feeding animals. The knowledge of extent and mode of inhibition of specific compounds, which are present in plant essential oils, may contribute to the successful application of such natural preservatives in foods since certain combinations of second metabolites provide a high antioxidant activity.

Keywords: rapeseed oil, olive oil, rice oil, rosemary essential oil, 2-thiobarbituric acid reactive substances, lipid peroxidation.

Rosemary (Rosmarinus officinalis L., Lamiaceae) is a woody perennial herb, native to the Mediterranean region, but is now cultivated all over the world as an ornamental and aromatic plant [2]. The leaves of rosemary are commonly used for flavoring foods as a condiment, but this plant has also been widely used for different medicinal 
purposes [17]. $R$. officinalis can promote several pharmacological effects due to the interaction between the molecules of the plant and the organic systems. The effects demonstrated by this plant include 1) ability to attenuate asthma, atherosclerosis, cataract, renal colic, hepatotoxicity, peptic ulcer, inflammatory diseases, ischemic heart disease; 2) antioxidant and anti-inflammatory actions of rosmarinic acid; 3) control of hypercholesterolemia and oxidative stress and relief of physical and mental fatigue; 4) myocardial blood pressure reduction with rosmarinic acid; 5) antiulcer action; 6) lipid peroxidation reduction in heart and brain; 7) antiangiogenic and neuroprotective effects of carnosic acid and carnosol; 8) prevention of problems related to atherosclerosis; 9) anticancer and antiproliferative effects; 10) antiviral; and antimicrobial actions; 11) hepatoprotective, nephroprotective and radioprotective-antimutagenic capacities; 12) glycemia reduction; 13) muscle relaxant and treatment for cutaneous allergy; 14) ability to treat depressive behavior [5].

Essential oils are complex mixtures of volatile compounds with a strong odor that are synthesized in several plant organs and exert diverse ecological functions [17, 21]. The essential oils have been reported to be useful in food preservation, fragrance industry and aromatherapy [7, 17]. Rosemary essential oil (REO) is a colorless or pale yellow liquid, with the characteristic odor of the plant, and consists mostly of monoterpenes such as 1,8-cineole, camphor, and $\alpha$-pinene [1]. Due to its antioxidant and antimicrobial activity [4, 15], REO is capable to extend the shelf-life of food products and maintain their quality during storage. Therefore, it has already being used as a preservative in the food industry $[13,17]$.

Among the assortment of bioactive compounds in the essential oils, p-cymene, thymol, eugenol, carvacrol, isothiocyanate, cinnamaldehyde, cuminaldehyde, linalool, 1,8-cineol, $\alpha$-pinene, $\alpha$-terpineol, $\gamma$-terpinene, citral, and methyl chavicol are most familiar. These terpenes (monoterpenes and sesquiterpenes) and phenolics (alcohols, esters, aldehydes, and ketones) have been extracted from culinary herbs such as oregano, rosemary, basil, coriander, cumin, cinnamon, mint, sage, and lavender as well as from trees such as myrtle, fir, and eucalyptus [14].

In addition to acting as an antioxidant agent, the essential oil isolated from rosemary possesses various health benefits and therapeutic effects [17]. According to the recommendation of European Medicines Agency (EMA) from 2010, REO can be used for treating dyspepsia and mild spasmodic disorders of the gastrointestinal tract, as well as an adjuvant in the relief of minor muscular and articular pain and in minor peripheral circulatory disorders $[6,17]$. REO contains many important bioactive compounds, such as monoterpene hydrocarbons (camphene, verbenene, $\alpha$-pinene, $\beta$-pinene, limonene), oxygenated monoterpenes (1,8-cineole, linalool, camphor, borneol, verbenone) and sesquiterpenes ( $\beta$-cariofillene) [12].

Essential oils or natural extracts of $R$. officinalis are known to possess antimicrobial and antioxidant activities, and some applications of these extracts in food active packaging systems were reported in the literature [18]. As an example, rosemary active packaging was the most effective method to protect pork meat from the lipid oxidation compared to oxygen scavenger packaging [3]. Sirocchi and co-workers (2013) investigated the beneficial effects of REO in poultry against the proliferation of bacteria responsible for the formation of biogenic amines, and the way in which these systems contribute to the increased shelf life of fresh meat was studied, along with the preservation of its important nutrients [20].

One of the strategies in the food industry is to use antioxidants to inhibit lipid oxidation. Although synthetic chemicals like tertiary butylhydroquinone (TBHQ), butylated hydroxyanisole (BHA), and butylated hydroxytoluene (BHT) have been widely 
used in various food products as efficient antioxidants, consumers are demanding antioxidants from natural sources [16]. Rosemary extract is one of the most popular natural antioxidants on the market [24]. In addition, rosemary extract containing carnosol and carnosic acid has been reported to have antiproliferative and anti-inflammatory activity [22]. Rosemary extract would provide potential extra functional values in the food products as a natural antioxidant [11].

Thus, it is interesting to study the progress of lipid oxidation in plant oils under the same conditions with and without the addition of rosemary extract as antioxidant. We hypothesized that rosemary essential oil would inhibit or reduce lipid oxidation in plant oils due to the antioxidative properties of the essential oil. In addition, contents of the lipid peroxidation marker in the plant oils were monitored during the storage period to investigate if lipid oxidation or food composition can have effects on the fate of bioactive compounds in the plant oils during storage. The aim of this work was to investigate the content of 2-thiobarbituric acid reactive substances (TBARS) in the various plant oils (rapeseed oil, olive oil, rice oil) with the use of rosemary essential oil (Etja, Elblag, Poland) as antioxidant agent by monitoring the lipid peroxidation during one month storage period.

Materials and methods. Preparation of samples. The plant oils (rapeseed oil, olive oil, rice oil) was obtained from local shops. The plant oil samples $(5 \mathrm{~mL})$ were incubated with $0.1 \mathrm{~mL}$ of rosemary essential oil (Etja, Elblag, Poland) (final concentration was $20 \mu \mathrm{g} / \mathrm{mL}$ ) at $25{ }^{\circ} \mathrm{C}$ for 40 days. This reaction mixture was shaken gently while being incubated for a fixed interval at $25^{\circ} \mathrm{C}$. Samples were removed at $0,8,15$, and 40 days of storage for analysis. The rapeseed oil, olive oil, and rice oil were used as the control samples.

Assay of 2-thiobarbituric acid reactive substances (TBARS). Lipid oxidation was evaluated by 2-thiobarbituric acid reactive substances (TBARS) according to the method described by Kamyshnikov (2004) with some modifications. Briefly, $0.1 \mathrm{~mL}$ of sample was added with $2 \mathrm{~mL}$ of distilled water, $1 \mathrm{~mL}$ of $20 \%$ trichloroacetic acid and $1 \mathrm{~mL}$ of 2-thiobarbituric acid in a test tube and, the tube content was immediately vortexed. Following water bath treatment at $100{ }^{\circ} \mathrm{C}$ for $15 \mathrm{~min}$, the tube content was cooled rapidly down to room temperature and centrifuged at $1000 \times \mathrm{g}$ for $10 \mathrm{~min}$. Then, absorbance was measured at $540 \mathrm{~nm}$ with a spectrophotometer (Specol 11, Carl Zeiss Jena, Germany) against blind (2.1 mL distilled water and $2 \mathrm{~mL}$ TCA-TBA solution). TBARS were calculated as $\mu$ moles malonic dialdehyde (MDA) per L of the sample [8].

Statistical analysis. Results are expressed as the mean. All variables were tested for normal distribution using the Kolmogorov-Smirnov test $(\mathrm{P}>0.05)$. Significance of differences in the lipid peroxidation biomarker in the samples (significance level at $\mathrm{p}<0.05)$ was examined using the Kruskal-Wallis test by ranks according to Zar (1999) [25]. All statistical calculations were performed on separate data from each sample with STATISTICA 8.0 software (StatSoft, Krakow, Poland).

Results and discussion. The TBARS assay measures the secondary oxidation products responsible for oxidative rancidity [23]. The effect of the REO on oxidative stability of the various plant oils (rapeseed oil, olive oil, rice oil) was evaluated throughout 40 days of storage. The inclusion of the REO in plant oils and storage time significantly affected TBARS values (Figs 1-3).

The effect of the interaction of the addition of REO and storage time on TBARS value in the rapeseed oil was presented in Fig. 1.

Lipid oxidation increased significantly $(\mathrm{p}<0.001)$ during storage, particularly in the control sample (the rapeseed oil), which showed the highest increase at 8 days (19fold increased) and at 40 days (14.4-fold increased). The REO decreased lipid oxidation 
compared to the control sample by $23.9 \%(\mathrm{p}<0.05)$ at 8 days and by $9.4 \%(\mathrm{p}>0.05)$ at 40 days. At 15 days, the TBARS values reached approximately $22.31 \mu \mathrm{mols} \cdot \mathrm{mL}^{-1}$, corresponding to a lipid oxidation increase of approximately $33.8 \%(\mathrm{p}>0.05)$ for samples enriched by REO (Fig. 1).

Fig. 2 illustrates the interaction effect of REO and storage time on the malonic dialdehyde (MDA) concentration in olive oil samples during 40 days of storage. Addition of REO increase significantly TBARS values only at 8 days of the storage. The highest TBARS value was determined in control samples at 15 days of the storage. The reduction of the lipid oxidation was the highest at 40 days as compared to the start of the study (Fig. 2).

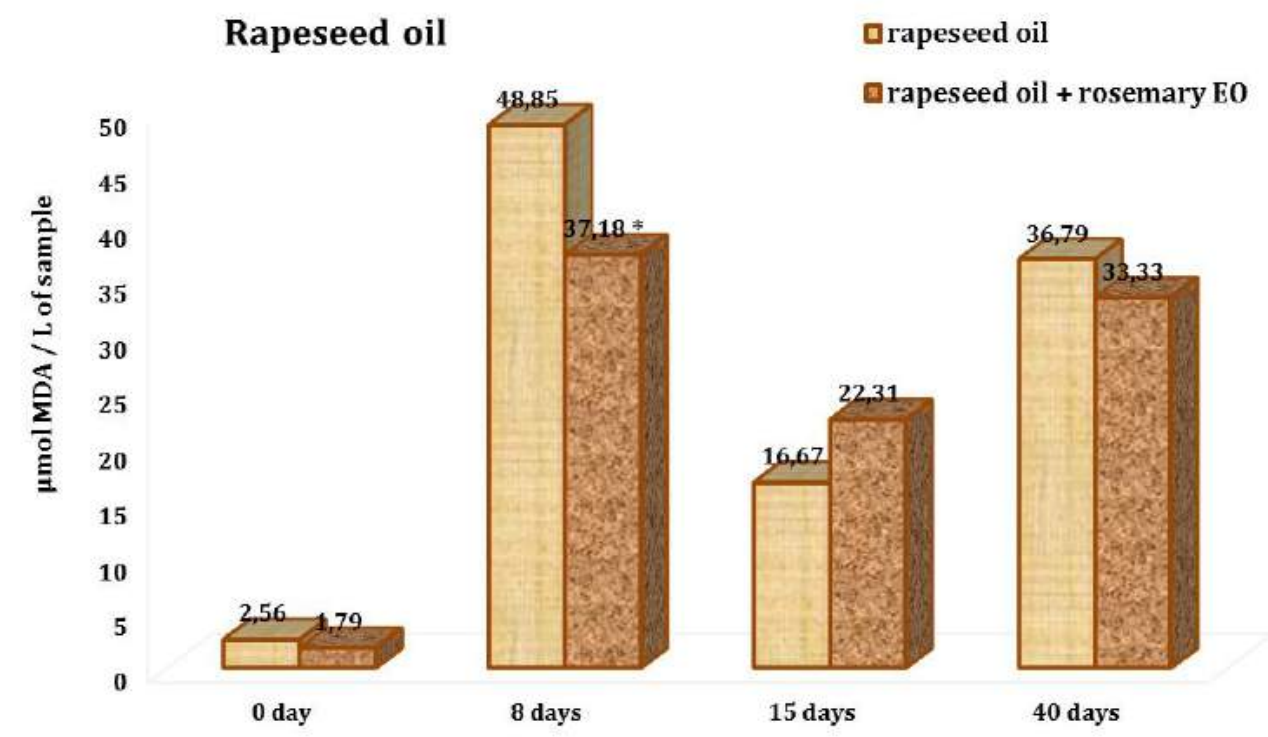

Fig. 1. The effect of the addition of rosemary essential oil and storage time on TBARS value (a biomarker of lipid peroxidation)in the rapeseed oil. * means with different superscripts are significantly different $(p<0.05)$.

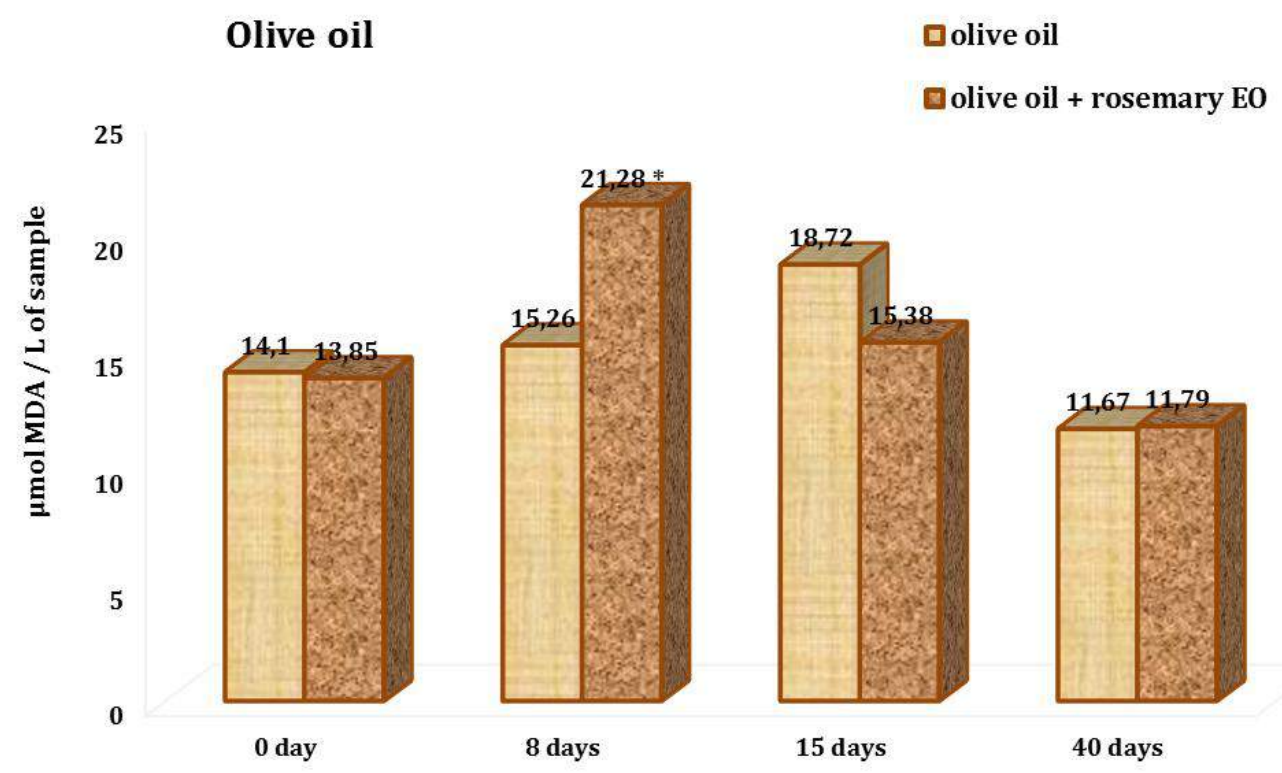

Fig. 2. The effect of the addition of rosemary essential oil and storage time on TBARS value (a biomarker of lipid peroxidation)in the olive oil. * means with different superscripts are significantly different $(p<0.05)$. 
An important observation is that the mean TBARS values of rice oil samples at the end of the storage (40 days) were at the same level (0, 8, and 15 days). REO added to rice oil induced the increase of TBARS level at 8 days (by $23.7 \%, \mathrm{p}<0.05$ ) and 0 days (by 64.4\%, p<0.05), respectively (Fig. 3).

As shown in Figs 2 and 3, the increase of TBARS levels in rice and olive oils samples enriched by REO during 8 days demonstrated that oxidative reactions took place during storage. On the other hand, treatment by REO was significantly effective to decrease the TBARS concentration in the rapeseed oil at 8 days of the storage period (Fig. 1).

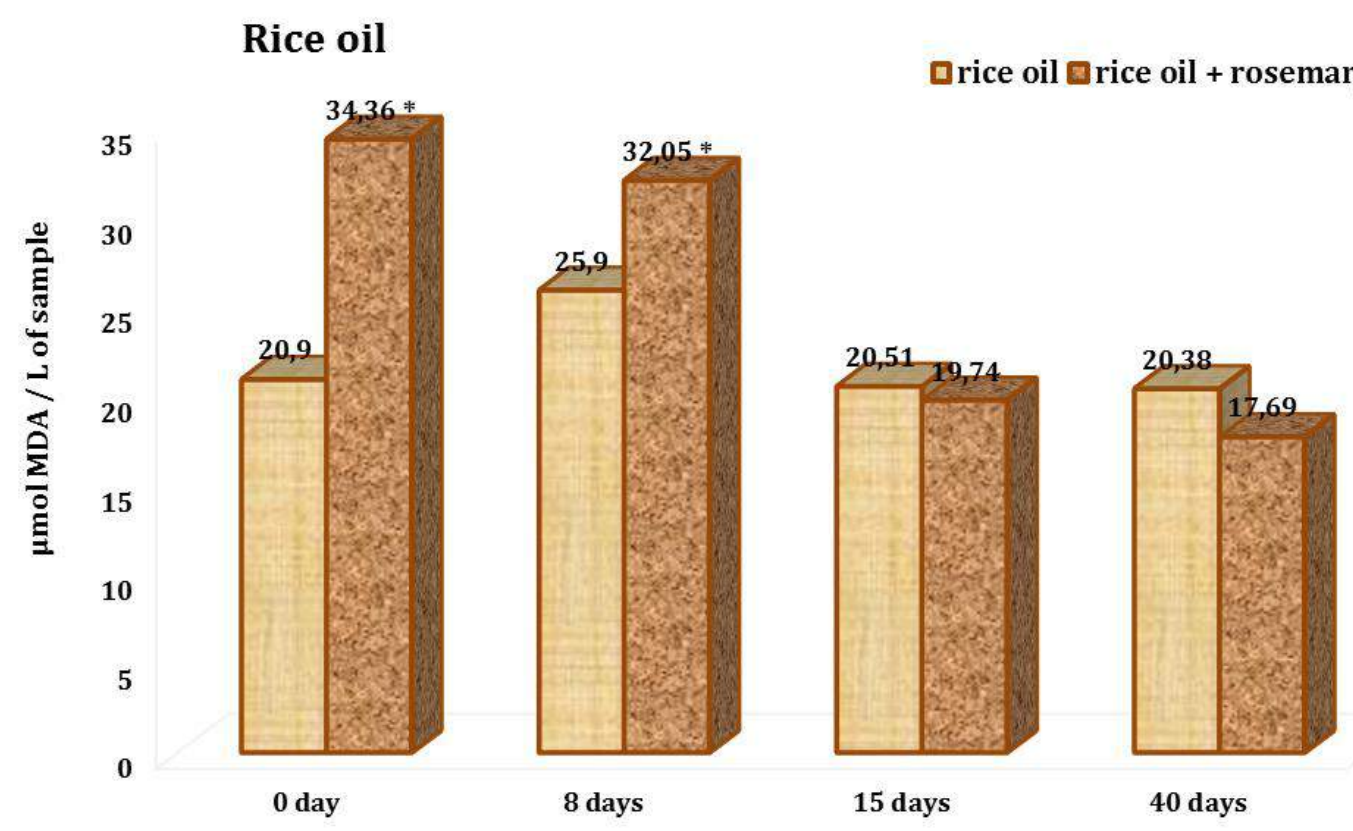

Fig. 3. The effect of the addition of rosemary essential oil and storage time on TBARS value (a biomarker of lipid peroxidation)in the rice oil.

* means with different superscripts are significantly different $(p<0.05)$.

Lipid oxidation is a very complex process initiated by peroxidation of the unsaturated fatty acid in phospholipid membranes to form primary oxidation products, hydroperoxides. The hydroperoxides decompose into further secondary oxidation products, such as aldehydes, ketones, alkenes and alcohols that cause off-flavors and odors in meat, which negatively affect the acceptability and overall quality of food products [10].

Essential oils play multiple, crucial roles as antioxidants, food pathogen inhibitors, shelf-life enhancers, texture promoters, organoleptic agents and toxicity-reducing agents. For their versatility, they appear promising as food preservatives. Several research findings in recent times have validated their potential as functional ingredients in meat and fish processing [14].

For example, Saoudi and co-workers (2016) have improved the oxidative stability of soybean oil by using aromatic plants. Soybean oil flavored with rosemary (ROS) and soybean oil flavored with thyme (THY) were subjected to heating for $24 \mathrm{~h}$ at $180^{\circ} \mathrm{C}$. The samples were analyzed every $6 \mathrm{~h}$ for their total polar compounds, anisidine values, oxidative stability, and polyphenols content. The tocopherols content was determined and volatile compounds were also analyzed. After $24 \mathrm{~h}$ of heating, the incorporation of these plants using a maceration process reduced the polar compounds by $69 \%$ 
and $71 \%$ respectively, in ROS and THY compared to the control. Until $6 \mathrm{~h}$ of heating, the ROS kept the greatest oxidative stability. The use of the two extracts preserves approximately $50 \%$ of the total tocopherols content until $18 \mathrm{~h}$ for the rosemary and $24 \mathrm{~h}$ for the thyme flavored oils. Volatile compounds known for their antioxidant activity were also detected in the formulated oils [19].

In the study of Bozin and co-workers (2007), the essential oils of rosemary (Rosmarinus officinalis L.) and sage (Salvia officinalis L.) were analyzed by means of gas chromatography-mass spectrometry and assayed for their antimicrobial and antioxidant activities. Antimicrobial activity was tested against 13 bacterial strains and 6 fungi, including Candida albicans and 5 dermatomycetes. The most important antibacterial activity of both essential oils was expressed on Escherichia coli, Salmonella typhi, S. enteritidis, and Shigellasonei. A significant rate of antifungal activity, especially of essential oil of rosemary, was also exhibited. Antioxidant activity was evaluated as a free radical scavenging capacity (RSC), together with the effect on lipid peroxidation (LP). RSC was assessed by measuring the scavenging activity of essential oils on 2,2-diphenyl-1-picrylhydrazyl (DPPH) and hydroxyl radicals. Effects on LP were evaluated following the activities of essential oils in $\mathrm{Fe}^{2+} /$ ascorbate and $\mathrm{Fe}^{2+} / \mathrm{H}_{2} \mathrm{O}_{2}$ systems of induction. Investigated essential oils reduced the DPPH radical formation $\left(\mathrm{IC}_{50}=\right.$ $3.82 \mu \mathrm{g} / \mathrm{mL}$ for rosemary and $1.78 \mu \mathrm{g} / \mathrm{mL}$ for sage) in a dose-dependent manner. Strong inhibition of lipid peroxidation in both systems of induction was especially observed for the essential oil of rosemary [4].

Lipid oxidation of fish oil enriched cow milk and soy milk supplemented with rosemary extract stored at $2{ }^{\circ} \mathrm{C}$ was studied by Qiu and co-workers (2018). Both peroxide value and volatile secondary lipid oxidation products were determined to monitor the progress of lipid oxidation. Rosemary extract inhibited lipid oxidation in fish oil enriched cow milk. In contrast, soy milk samples having much higher unsaturated fatty acid content showed higher lipid oxidation stability compared to cow milk. Reduction in the content of chlorogenic acid during storage suggested that this compound may contribute to the lipid oxidation stability of fish oil enriched soy milk product. Total carnosic acid and carnosol concentration declined much faster in soy milk than in cow milk [16].

Rosemary essential oil contains bioactive having antioxidant and antimicrobial properties. Sirocchi and co-workers (2017) have investigated the effect of REO combined with modified atmosphere packaging conditions (MAP), aerobic vacuum or high $\mathrm{O}_{2}$, to extend the shelf life of beef. Beef slices were wrapped in special three-layer sheets of packaging material, some with a coating of REO (active packaging, AP), and some without REO (nonactive packaging, NAP), and stored at $4{ }^{\circ} \mathrm{C}$ for 20 days. Microbiological analysis of the meat showed that the counts of Psychrophilic, Brochothrixthermosphacta, Enterobacteriaceae and Pseudomonas spp. bacteria were lower in AP meat than in NAP meat, especially in high- $\mathrm{O}_{2}$ conditions. Packaging with REO and high- $\mathrm{O}_{2}$ conditions proved to be the best form for prolonging the shelf life of beef, extending it until day 15. Moreover, the use of REO in combination with different atmosphere conditions also had a positive influence on the color parameters, in particular, the redness $\mathrm{a}^{*}$. The results obtained lead to conclude that the combination of REO and MAP could have important applications in the food packaging industry for prolonging the shelf life of fresh meat [20].

The effects of an alginate-based edible coating containing natural antioxidants (rosemary and oregano essential oils) on lipid oxidation, color preservation, water losses, texture and $\mathrm{pH}$ of beef steaks during 14 days of the display were studied by Vital and co-workers (2016). The essential oil, edible coating and beef antioxidant activities, 
and beef consumer acceptability were also investigated. The edible coatings decreased lipid oxidation of the meat compared to the control. The coating with oregano was most effective (46.81\% decrease in lipid oxidation) and also showed the highest antioxidant activity. The coatings significantly decreased color losses, water losses, and shear force compared to the control. The coatings had a significant effect on consumer perception of odor, flavor and overall acceptance of the beef. In particular, the oregano coating showed significantly high values (approximately 7 in a 9-point scale). Active edible coatings containing natural antioxidants could improve meat product stability and therefore have potential use in the food industry [23].

The treatment with basil and rosemary essential oils (EOs), as natural biopreservative compounds, could present a high-potential application in the seafood industry. Karoui and Hassoun (2017) have evaluated the impact of rosemary and basil EOs on the quality of Atlantic mackerel fillets stored at $2{ }^{\circ} \mathrm{C}$ up to 15 days. Atlantic mackerel (Scomberscombrus) fillets were periodically evaluated to assess their textural, color, physicochemical, and spectral characteristics. The results indicated that rosemary and basil treatments were effective for inhibiting the formation of total volatile basic nitrogen (TVB-N) and lipid oxidation products during storage. The shelf life of Atlantic mackerel fillets treated with rosemary and basil EOs was extended by 2 and 5 days, respectively, compared to the control group. Similar results were obtained with 2thiobarbituric acid-reactive substance analysis, which demonstrated an extended shelf life of Atlantic mackerel immersed with rosemary and basil EOs of 2 and 3 days, respectively, compared to the control group. The factorial discriminant analysis applied on the concatenated first five principal components corresponding to the physicochemical, textural, color, and fluorescence measurements allowed clear discrimination of the three groups because a correct classification rate of $93.3 \%$ was obtained [9].

Conclusions. In the present study, the content of 2-thiobarbituric acid reactive substances (TBARS) in the various plant oils (rapeseed oil, olive oil, rice oil) with the use of rosemary essential oil (Etja, Elblag, Poland) as an antioxidant agent by monitoring the lipid peroxidation during one month storage period were evaluated. Lipid peroxidation retarding capacity of rosemary essential oil was found obviously promising. These antioxidant activities seem to be attributed to antioxidant compounds present in the rosemary essential oil. The rosemary essential oil decreased lipid oxidation in the rapeseed oil compared to the control sample by $23.9 \%(\mathrm{p}<0.05)$ at 8 days and by $9.4 \%$ ( $>>0.05)$ at 40 days. Addition of rosemary essential oil to olive oil increased significantly TBARS values only at 8 days of the storage. The reduction of the lipid oxidation was the highest at 40 days as compared to the start of the study. Rosemary essential oil added to rice oil induced the increase of TBARS level at 8 days (by $23.7 \%, p<0.05$ ) and 0 days (by $64.4 \%, \mathrm{p}<0.05$ ), respectively. Consequently, rosemary essential oil could be successfully added to various plant oils as a natural antioxidant source. The knowledge of extent and mode of inhibition of specific compounds, which are present in plant essential oils, may contribute to the successful application of such natural preservatives in foods since certain combinations of second metabolites provide a high antioxidant activity.

\section{References}

1. al-Sereiti, M. R., \& Abu-Amer, K. M., Sen, P. (1999). Pharmacology of rosemary (Rosmarinus officinalis Linn.) and its therapeutic potentials. Indian J. Exp. Biol. $37(2), 124-130$. 
2. Begum, A., \& Sandhya, S., Shaffath Ali, S., Vinod, K. R., Reddy, S., Banji, D. (2013). An in-depth review of the medicinal flora Rosmarinus officinalis (Lamiaceae). Acta Sci. Pol. Technol. Aliment., 12(1), 61-73.

3. Bolumar, T., \& LaPeña, D., Skibsted, L. H., Orlien, V. (2016). Rosemary and oxygen scavenger in active packaging for prevention of high-pressure induced lipid oxidation in pork patties. Food Packaging and Shelf Life, 7, 26-33.

4. Bozin, B., \& Mimica-Dukic, N., Samojlik, I., Jovin, E. (2007). Antimicrobial and antioxidant properties of rosemary and sage (Rosmarinus officinalis L. and Salvia officinalis L., Lamiaceae) essential oils. J. Agric. Food Chem., 55(19), 7879-7885.

5. de Oliveira, J. R., \& Camargo, S.E.A., de Oliveira, L. D. (2019). Rosmarinus officinalis L. (rosemary) as therapeutic and prophylactic agent. J. Biomed. Sci., 26(1), 5.

6. European Medicines Agency. Community herbal monograph on Rosmarinus officinalis L., aetheroleum. 2010. [http://www.ema.europa.eu/docs/en_GB/document_library/Herbal_Community_herbal_monograph/2011/01/WC500101493.pdf]

7. Kadri, A., \& Zarai, Z., Ben Chobba, I., Bekir, A., Gharsallah, N., Damak, M., Gdoura, R. (2011). Chemical constituents and antioxidant properties of Rosmarinus officinalis L. essential oil cultivated from South-Western Tunisia. J. Med. Plants Res., 5, 5999-6004.

8. Kamyshnikov, V. S. (2004). A reference book on the clinic and biochemical researches and laboratory diagnostics, MEDpress-inform, Moscow.

9. Karoui, R., \& Hassoun, A. (2017). The efficiency of Rosemary and Basil Essential Oils on the Shelf-Life Extension of Atlantic Mackerel (Scomberscombrus) Fillets Stored at $2^{\circ} \mathrm{C}$. J. AOAC Int., 100(2), 335-344.

10. Kumar, Y., \& Yadav, D. N., Ahmad, T., Narsaiah, K. (2015). Recent Trends in the Use of Natural Antioxidants for Meat and Meat Products. Comprehensive Reviews in Food Science and Food Safety, 14, 796-812.

11. Martin, D., \& Salas-Perez, L., Villalva, M., Vázquez L., Garcia-Risco, M.R., Jaime, L., Reglero, G. (2017). Effect of alkylglycerol-rich oil and rosemary extract on oxidative stability and antioxidant properties of a cooked meat product. European Journal of Lipid Science and Technology, 118, 1600412.

12. Napoli, E. M., \& Curcuruto, G., Ruberto, G. (2010). Screening of the essential oil composition of wild Sicilian Rosemary. Biochemical Systematics and Ecology, $38,659-670$.

13. Ojeda-Sana, A. M., \& van Baren, C. M., Elechosa, M. A., Juarez, M. A., Moreno, S. (2013). New insights into antibacterial and antioxidant activities of rosemary essential oils and their main components. Food Control, 31, 189-195.

14. Patel, S. (2015). Plant essential oils and allied volatile fractions as multifunctional additives in meat and fish-based food products: a review. Food Addit. Contam. Part A Chem. Anal. Control Expo Risk Assess., 32(7), 1049-1064.

15. Prabuseenivasan, S, \& Jayakumar, M, Ignacimuthu, S. (2006). In vitro antibacterial activity of some plant essential oils. BMC Complement.Altern. Med., 6, 39.

16. Qiu, X., \& Jacobsen, C., Sørensen, A. M. (2018). The effect of rosemary (Rosmarinus officinalis L.) extract on the oxidative stability of lipids in cow and soy milk enriched with fish oil. Food Chem., 263, 119-126.

17. Rašković, A., \& Milanović, I., Pavlović, N., Ćebović, T., Vukmirović, S., Mikov, M. (2014). Antioxidant activity of rosemary (Rosmarinus officinalis L.) essential oil and its hepatoprotective potential. BMC Complement. Altern. Med., 14, 225.

18. Realini, C. E., \& Marcos, B. (2014). Active and intelligent packaging systems for a modern society. Meat Science, 98, 404-419. 
19. Saoudi, S., \& Chammem, N., Sifaoui, I., Bouassida-Beji, M., Jiménez, I. A., Bazzocchi, I. L., Silva, S. D., Hamdi, M., Bronze, M. R. (2016). Influence of Tunisian aromatic plants on the prevention of oxidation in soybean oil under heating and frying conditions. Food Chem., 212, 503-511.

20. Sirocchi, V., \& Devlieghere, F., Peelman, N., Sagratini, G., Maggi, F., Vittori, S., Ragaert, P. (2017). Effect of Rosmarinus officinalis L. essential oil combined with different packaging conditions to extend the shelf life of refrigerated beef meat. Food Chem., 221, 1069-1076.

21. Teixeira, B., \& Marques, A., Ramos, C., Neng, N. R., Nogueira, J.M.F., Saraiva, J. A., Nunes, M. L. (2013). Chemical composition and antibacterial and antioxidant properties of commercial essential oils. Ind.Crop Prod., 43, 587-595.

22. Vicente, G., \& Molina, S., González-Vallinas, M., García-Risco, M. R., Fornari, T., Reglero, G., de Molina, A. R. (2013). Supercritical rosemary extracts, their antioxidant activity, and effect on hepatic tumor progression. The Journal of Supercritical Fluids, 79, 101-108.

23. Vital, A. C., \& Guerrero, A., MonteschioJde, O., Valero, M. V., Carvalho, C. B., de Abreu Filho, B.A., Madrona, G. S., do Prado, I.N. (2016). Effect of Edible and Active Coating (with Rosemary and Oregano Essential Oils) on Beef Characteristics and Consumer Acceptability. PLoS One, 11(8), e0160535.

24. Xie, J., \& VanAlstyne, P., Yang, X. (2017). A review on rosemary as a natural antioxidation solution. European Journal of Lipid Science and Technology, 119, 1600439.

25. Zar, J. H. (1999). Biostatistical Analysis, 4th ed., Prentice Hall Inc., New Jersey.

ВЛИЯНИЕ ЭФИРНОГО МАСЛА РОЗМАРИНА НА ПЕРЕКИСНОЕ ОКИСЛЕНИЕ ЛИПИДОВ В РАЗЛИЧНЫХ РАСТИТЕЛЬНЫХ МАСЛАХ

Доценко А., Коновод А., Белая Е., Климович В., Трухан М., Ткаченко Г., Институт биологии и охраны окружающей среды Поморской Академии в Слупске (Слупск, Польша)

Мы предположили, что эфирное масло розмарина будет препятствовать или уменьшать окисление липидов в растительных маслах из-за антиоксидантных свойств. Цель этого исследования состояла в том, чтобы исследовать содержание веществ, реагирующих с 2-тиобарбитуровой кислотой (ТБК-активный продукт), в различных растительных маслах (рапсовое масло, оливковое масло, рисовое масло) с использованием эфирного масла розмарина (Еtја, Эльблонг, Польша) в качестве антиоксиданта путем мониторинга перекисного окисления липидов в течение одного месяи хранения.

Эфирное масло розмарина снижало окисление липидов в рапсовом масле по сравнению с контрольным образиом на 23,9\% $(p<0,05)$ через 8 дней и на 9,4\% $(p>0,05)$ через 40 дней хранения. Добавление эфирного масла розмарина к оливковому маслу значительно увеличивало значения ТБК-активных продуктов только через 8 дней хранения. Снижение окисления липидов было самым высоким через 40 дней по сравнению с началом исследования. Эфирное масло розмарина, добавленное к рисовому маслу, вызывало повышение уровня ТБК-активных продуктов через 8 дней (на 23,7\%, p<0,05) и в начале эксперимента (на 64,4\%, $<<0,05$ ), соответственно. Способность эфирного масла розмарина замедлять перекисное окисление липидов оказалась явно многообещающей стратегией хранения. Эта активность, по-видимому, связана с антиоксидантными соединениями, присутствующими в эфирном масле розмарина. 
Следовательно, эфирное масло розмарина можно добавлять в различные растительные масла в качестве природного источника антиоксидантов в кормлении животных. Знание степени и способа ингибирования конкретных соединений, которые присутствуют в эфирных маслах растений, может способствовать успешному применению таких натуральных консервантов в пищевых продуктах, поскольку определенные комбинации вторичных метаболитов обеспечит высокую антиоксидантную активность.

Ключевые слова: рапсовое масло, оливковое масло, рисовое масло, эфирное масло розмарина, реактивные вещества 2-тиобарбитуровой кислоты, перекисное окисление липидов.

\section{ВПЛИВ ЕФІРНОЇ ОЛІЇ РОЗМАРИНУ НА ПЕРЕКИСНЕ ОКИСНЕННЯ ЛІПІДІВ У РІЗНИХ ВИДАХ РОСЛИННИХ ОЛІЙ}

ДоченкоА., Коновод А., Біла С., Климович В., Трухан М., Ткаченко Г., Інститут біологї та охорони навколишнього середовища Поморської Академії в Слупську (Слупськ, Польща)

Ми припустили, щуо ефірна олія розмарину буде попереджувати або зменшувати перекисне окиснення ліпідів в рослинних оліях завдяки антиоксидантним властивостям. Мета роботи полягала у дослідженні вмісту речовин, щзо реагують з 2-тіобарбітурової кислотою (ТБК-активні продукти) в різних рослинних оліях (ріпакова олія, оливкова олія, рисова олія) після використання ефірної олії розмарину (Еtја, Ельблонг, Польща) як антиоксиданту шляхом моніторингу перекисного окиснення ліпідів впродовж одного місяия зберігання.

Ефірна олія розмарину знижувала окиснення ліпідів в ріпаковій олії в порівнянні з контрольним зразком на 23,9\% $(p<0,05)$ після 8 днів $і$ на 9,4\% $(p>0,05)$ після 40 днів зберігання. Додавання ерірної олії розмарину до оливкової олії значно збільшувало вміст ТБК-активних продуктів тільки через 8 днів зберігання. Зниження окиснення ліпідів було найвищим через 40 днів в порівнянні з початком дослідження. Ефірна олія розмарину, додана до рисової олії, викликало підвищення рівня ТБК-активних продуктів після 8 днів зберігання (на 23,7\%, $p<0,05)$ і на початку експерименту (на 64,4\%, p<0,05), відповідно. Здатність ефрірної олії розмарину сповільнювати перекисне окиснення ліпідів виявилося багатообіияючою стратегією в зберіганні рослинних олій. Ця активність, мабуть, пов'язана з антиоксидантними сполуками, присутніми в ефірній олії розмарину.

Отже, ефірну олію розмарину можна додавати в різні рослинні олії як природне джерело антиоксидантів у годівлі тварин. Знання ступеня $i$ способу інгібування конкретних сполук, які присутні в ефірних оліях рослин може сприяти успішному застосуванню таких натуральних консервантів в харчових продуктах, оскільки певні комбіначії вторинних метаболітів забезпечать високу антиоксидантну активність.

Ключові слова: ріпакова олія, оливкова олія, рисова олія, ефірна олія розмарину, ТБК-активні продукти, перекисне окиснення ліпідів. 